\title{
PELUANG PENANAMAN MODAL ASING DALAM PENINGKATAN PEREKONOMIAN NEGARA PASCA PANDEMI COVID 19
}

\author{
Besse Tenriabeng Mursyid \\ Institut Agama Islam Negeri Palu \\ bmursyid@iainpalu.ac.id
}

\begin{abstract}
:
In terms of the economic development of a nation it cannot be separated from economic activities that are stable in a country, on the other hand it is undeniable that now the world is struggling against the Covid19 pandemic which is known together with all countries is intensively making movements aimed at Minimizing the spread of the corona virus, recorded based on data from the Google news site related to the development of Covid-19 cases throughout the country, the total cases worldwide were recorded at 50,794,593 with cases of patients dying as many as 1,262,199 Various policies were created by the government in order to attract the attention of foreign investors to enter Indonesia to invest, one of which is the open door policy to improve the country's economy after the Covid-19 pandemic in the future.
\end{abstract}

Keyword: Econom; Increase; Foreign Investment; Pandemic Covid-19.

\begin{abstract}
Abstrak:
Dalam hal pembangunan perekonomian suatu bangsa tidak dapat terlepas dari aktifitasaktifitas perekonomian yaang sifatnya stabil pada suatu negara, disisi lain tidak bisa dipungkiri sekarang dunia sedang dalam masa berjuang melawan Pandemi covid-19 yang diketahui bersama semua Negara sedang gencar membuat gerakan-gerakan yang bertujuan meminimalisisr penyebaran virus corona, tercatat berdasarkan data dari situs news google terkait perkembangan kasus Covid-19 diseluruh Negara adalah Total Kasus seluruh dunia tercatat sebayak 50.794.593 dengan kasus pasien meninggal dunia sebayak 1.262.199. Berbagai kebijakan dilahirkan pemerintah demi menarik perhatian investor asing agar masuk ke Negara Indonesia untuk berinvestasi, salah satunya dengan cara kebijaksanaan pintu terbuka guna meningkatkan perekonomian Negara pasca pandemic covid-19 kedepan.
\end{abstract}

Kata Kunci: Perekonomian; Peningkatan; Investasi Asing; Pandemi Covid 19.

\section{A. PENDAHULUAN}

Tujuan dan arah perkembangan suatu pembangunan negara merupakan hal yang tidak dapat dipungkiri untuk menjadi sebuah pembahasan yang tidak akan perna habisnya oleh kalangan pemerintah dalam menjalankan tujan pekerjaannya

TADAYUN:

Jurnal Hukum Ekonomi Syariah

Vol.1 No.2, Juli-Desember 2020 | 169

E-ISSN: 2774-4914 
demi kepentingan rakyat dan negaranya, terlepas dari itu semua penulis berargumen bahwa dalam hal pembangunan perekonomian suatu bangsa tidak dapat terlepas dari aktifitas-aktifitas perekonomian yaang sifatnya stabil pada suatu negara, disis lain tidak bias dipungkiri sekarang duni sedang dalam masa berjuang melawan Pandemi covid 19 yang diketahui bersama semua Negara sedang gencar membuat gerakangerakan yang bertujuan meminimalisisr penyebaran virus corona, tercatat berdasarkan data dari situs news google terkait perkembangan kasus Covid 19 diseluruh Negara adalah Total Kasus seluruh dunia tercatat sebayak 50794.593 dengan kasus pasien meninggal dunia sebayak 1.262.199 jiwa, tercatat penambahan kasus sejak 24 oktober 2020 hingga 6 November 2020 sebayak +6.963.625 jiwa, dalam informasi yang ada, negara Amerika Serikat masih tercatat sebagai Negara tertinggi kasus covid 19 sebayak 30.723 dengan kasus meninggal dunia sebayak 238.248 kasus. ${ }^{1}$ Dilihat dari data informasi yang didapatkan oleh penulis, jelas kasus pandemic covid 19 bukanlah hal yang main-main, diperlukan perhatian yang sangat serius bagi semua pihak.

Banyak hal yang dilakukan pemerintah demi menjaga kestabilan perekonomian itu sendiri, mulai dari peminjaman modal pada negara maju dengan tujuan menopang perekonomian negara hingga membuka kesempatan investor asing untuk berinvestasi dinegaranya dengan melakukan trik-trik demi menarik perhatian investor asing agar dengan modalnya masuk kenegaranya dengan harapan pemerintah dapat menuai dari hasil investasi atau penanaman modal investor asing itu sendiri, walaupun diketahui bersama batasan-batasan yang diberlakukan oleh setiap Negara merupakan hal yang menjadi salah satu kendala dalam menjalankan strategi-strategi Negara dalam peningkatan perekonomian Negara. Semua upaya upaya tersebut tidak lain dan tidak bukan merupakan tujuan negara demi mencapai pembangunan negara. Oleh Aminuddin Ilham, SH. Salah satu pakar hukum mengatakan bahwa:

\footnotetext{
${ }^{1}$ https://news.google.com/covid19/map?hl=id\&gl=ID\&ceid=ID\%3Aid
} 
“Pembangunan terutama berarti mengelola kekuatan ekonomi potensial menjadi kekuatan ekonomi rill melalui penanaman modal “ 2

Dalam hal ketersediaan modal yang dapat segera dikerahkan untuk melaksanakan pembangunan nasional sangat tidak memadai, sehingga olehnya alasan pertama pemerintah melakukan berbagai kebijakan-kebijakan dan pendekatan kepada negara-negara yang dapat memberikan bantuannyakepada Indonesia, alhasil dari upaya tersebut dapat kita lihat bahwa kini kenyataannya indonesia yang merupakan negara berkembang merupakan salah satu negara dengan jumlah hutang yang cukup besar pada negara maju yang memberikan pinjaman paska Moneter yang dihadapi bagsa. Pada keadaan tersebut mendorong pemerintah untuk mencari alternatif lain selain bantuan pinjaman luar negeri yang selama ini menopang pembangunan negara berkembang atau yang sedang berkembang yakni, dengan menanggalkan penanaman modal khususnya Penanaman Modal Asing (PMA). Berbagai cara dilakukan pemerintah demi menarik perhatian investor asing agar masuk kenegara Indonesia untuk berinvestasi, salah satunya dengan cara kebijaksanaan Pintu terbuka. Dalam hal ini tidak dapat dipungkiri timbulnya pro dan kontra dikalangan masyarakat, salah satu masalah tersebut yang kali ini penulis akan angkat dalam jurnal ini adalah masalah Investasi asing dan pembangunana perekonomian negara, maka timbulah suatu pertanyaan sebelumnya harus kita ketahui dengan jelas tentang "apa itu penanaman modal atau berinvestasi?" dan yang kedua yang lebih penting, mengenai "apakah investasi asing dapat berpengaruh dengan perkembangan perekonomian negara indonesia atau malah sebaliknya, hanya merusak kebudayaan perekonomian dan mematikan industri kecil dinegara indonesia".

Seperti yang dijelaskan diatas, bila mana kita ingin membandingkan dengan negara-negara lain, tentu saja penanaman modal diindonesia khususnya penanaman modal diindonesia khususnya Penanaman Modal Asing(PMA) belum memakan waktu yang lama dalam artian dikelola secara sungguh-sungguh. Penanaman modal diindonesia dikenal pertama kali melalui kebijaksanaan pemerintah Hindia Belanda

\footnotetext{
${ }^{2}$ Aminuddin Ilmar, Hukum penanaman modal, (Jakarta: Prenada Media, 2004), h. 2.
} 
yang memperkenankan masuknya modal asing Eropa untuk menanamkan usahanya dalam bidang perkebunan pada tahun 1870 yang jika dibandingkan dengan negaranegara lain yang jauh sebelum itu telah mengenal dan menjalankan Penanaman Modal Asing (PMA). ${ }^{3}$

Problematika yang kedua adalah mengenai maslah buruh pada awal munculnya Penanaman Modal Asing yang mungkin sedikit diuraikan pada Bab pertama ini. Berbagai perkembangan terjadi dengan variasi yang berbeda diantaranya terjadinya kenaikan produksi hasil bumi, adanya kewenangan bertindak bagi buruh untuk mendapatkan penghasil meskipun masih kecil karena bekerja sebagai buruh upah diperkebunan asing. Maka dengan adanya aturan yang dibuat pemerintah membuat tingkat derajat buruh atas pekerjaan yang dilakukan menjadi sedikit meningkat dibandingkan sebelumnya. Salah satu aturan yang dikeluarkan oleh pemerintah saat sekarang ini adalah Undang-Undang No.13 tentang ketenaga kerjaan, didalamnya di jelaskan mengenai kewenangan-keweangan buruh tanpa terkecuali buruh yang bekerja pada Investor asing yang berinvestasi didalam wilayah Indonesia sehingga hal tersebut membawa evek positif bagi perkembangan negara kita.

Maka melalui jurnal ini penulis akan memaparkan sedikit pikiran dan penjelasan yang penulis dapatkan lewat sedikit pengetahuan lewat berita, buku-buku serta aturan-aturan yang yang diberlakuan terkait dengan penanaman modal asing.

\section{B. PEMBAHASAN}

Menghindarkan dari pemikiran negatif terkait dengan peranan penanaman modal terkhusus pada penanaman modal asing (Foreign Direct Investment) maka dibutuhkan batasan terhadap definisi penanaman modal. Sehingga maksud yang ingin dicapai yakni pemahaman dan pandangan secara menyeluruh terkait penanaman modal menjadi lebih jelas, seperti yang tercantum didalam Undang-Undang no.25 tahun 2007 pada pasa 1 dan 3 yang lebis spesifik lagi tentang penanaman modal asing, bunyinya adalah sebagai berikut.

\footnotetext{
3 Lihat: Jochen Roppke, kebebasan yang terhambat; perkembangan ekonomi diIndonesia, www.artikelhukum.com
} 
Pasal 1:

"Penanaman modal adalah segala bentuk kegiatan menanam modal, baik oleh penanam modal dalam negeri maupun penanam modal asing untuk melakukan usaha di wilayah negara Republik Indonesia."

Pasal 2:

"Penanaman modal asing adalah kegiatan menanam modal untuk melakukan usaha di wilayah negara Republik Indonesia yang dilakukan oleh penanammodal asing, baik yang menggunakan modal asing sepenuhnya maupun yang berpatungan denganpenanam modal dalam negera" 5

Teori yang diketahui dari kaitan antara Investor dan negara penerima (host country) terlebih pada Foreign Direct Investment atau penanaman modal asing itu memiliki berbagai variasi. Teori dimaksud adalah sebagai berikut :

a. Teori pertama, menujukan terdapatnya perilaku yang ekstrim ialah tidak menginginkan munculnya dependensi negara pada penanaman modal, terkhusus modal asing, sehingga secara tegas menyangkal adanya penananman modal asing karena dianggap sebagai kontinuitas dari proses kapitalisme. Teori ini dipengaruhi oleh Karl Marx dan Robert Magdoff. ${ }^{6}$

b. Teori kedua, berupa teori yang bersifat nasionalisme dan populisme yang pada dasarnya diliputi kekhawatiran akan adanya dominasi penanaman modal asing. Oleh sebab itu, menurut paham teori ini bahwa kehadiran penanaman modal asing berakibat adanya pembagian keuntungan yang tidak setara sehingga posisi pihak penanam modal asing lebih menguntungkan, oleh karena itu menjadikan negara penerima memberikan batasan ketat dalam kegiatan penanaman modal asing. Teori ini dipelopori oleh Streeten dan Stephen Hymer.

c. Teori ketiga, memandang kedudukan penanaman modal asing menurut ekonomi tradisional serta meninjau pada sisi realitasnya, sebagaimana penanaman modal asing bisa berpengaruh pada pembaharuan serta

\footnotetext{
${ }^{4}$ Undang-Undang No.25 tahun 2007 tentang Penanaman Modal

${ }^{5}$ Undang-Undang No.25 tahun 2007 tentang Penanaman Modal

${ }^{6}$ Arsyad, Pengantar Perencanaan dan Pembangunan Ekonomi Daerah, (Yogyakarta: BPFE,1991)

${ }^{7}$ Kuntjoro Jakti, Ekonomi Politik di Asia Pasifik, (Jakarta: Erlangga,1995), h. 128.
} 
perkembangan ekonomi negara penerima. Prosedur seperti ini bisa ditemukan pada indikasi pertumbuhan serta perkembangan ekonomi dunia dan sistem pasar beroperasi dengan atau tanpa fasilitas serta pengendalian dari negara penerima. Teori ini dipelopori oleh Raymound Vernon dan Charles P. ${ }^{8}$

Penjabaran dari variasi teori ini, menunjukan bahwa definisi dari penanaman modal atas tiap negara penerima bergantung kepada hubungan antara teori yang diikuti ataupun merupakan ragam dari keseluruhan teori. Kondisi ini dengan jelas bisa dilihat dari setiap peraturan yang ditetapkan pada suatu negara penerima pada aspek yang berkaitan dengan penanaman modal terkhusus penanaman modal asing yang tercantum pada peraturan undang-undang penanaman modal pada setiap negara. Dikemukakan oleh Todung Mulya Lubis bahwa jika dibaca ketentuan yang tertuang adalam pasal 1 UU No.1 tahun 1967 tentang PMA maka menurut penulis pengertian penanaman modal asing (PMA) agaknya berat ke equity, suatu fresh kapital yang datang dari luar negeri. ${ }^{9}$ Menurut penulis, pengertian yang dikemukakan oleh beliau sangatlah sempit. Pada Undang-undang penanaman Modal Asing, pasal 1 disebutkan bahwa:

"Pengertian penanaman modal asing didalam Undang-Undang ini hanyalah meliputi penanaman modal secara langsung yang diadakan menurut atau berdasarkan ketentuan Undang-Undang ini dan yang digunakan untuk menjalankan perusahaan di Indonesia, dalam arti bahwa pemilik modal secara lansung menanggung resiko dari penanaman modal tersebut." ${ }^{10}$

Isi pasal ini menerangkan pada prinsipnya penanaman modal asing mengandung tiga komponen pokok yakni:

a. Direct invesment (Penanaman modal secara langsung);

b. Modal dipergunakan untuk menjalankan perusahaan di Indonesia;

c. Pemilik modal memiliki resiko yang harus ditanggung.

Serupa dengan pengertian penanaman modal asing pada komponen pokok yang terkandung dalam pasal 1, yakni komponen yang pertama, bukan portofolio

\footnotetext{
${ }^{8}$ Henri Simamora, ManajemenPemasaran Internasional, (Jakarta: Salemba Empat, 2000), h. 421- 423.

${ }^{9}$ T.Mulya Lubis, Hukum Ekonomi, (Jakarta: Sinar Harapan, 1992), h. 23

${ }^{10}$ Undang-Undang Penanaman Modal Asing No.1 tahun 1967.
} 
investment yang mana pemilik modal tidak berpartisipasi dalam pengelolaan manajemen perusahaan melainkan hanya memiliki saham saja. sebaliknya yang dimaksud sesuai dengan pasal 1 yakni direct investment. Pengklasifikasian ini dibutuhkan agar dapat memudahkan kategorisasi yang termasuk bidang penanaman modal terkhusus penanaman modal asing serta yang tidak termasuk penanaman modal asing walaupun ada keterkaitan dengan unsur asing. ${ }^{11}$

\section{Pengaruh Penanaman Modal Asing Terhadap Perkembangan Perekonomian Indonesia Pasca Pandemi Covid 19}

Menurut penulis perkembangan perekonomian suatu negara dapat dikatakan sukses apabila segala bentuk usaha dan program yang dilakukan pemerintah berlangsung dengan baik juga feedback yang dihasilkan mampu memenuhi segala bentuk kecukupan negaranya. Penanaman modal asing atau investasi asing masuk kedalam wilayah indonesia dengan modal baik swasta atau dari pemerintah negara eksternal tidak sertamerta langsung diterima begitu saja oleh negara kita, diperlukan penilaian yang intensif yang sesuai dengan nilai-nilai pokok bangsa indonesia, hal tersebut diperuntukan agar menjaga segala kemungkinannya terjadi perusakan budaya dan ancaman bagi home industri milik masyarakat yang juga uahanya dengan modal kecil, lebih lanjut lagi, penanaman modal asing adalah penanaman modal yang diselanggarakan sesuai atas asas-asas yang telah ditetapkan dengan nilai-nilai bangsa, adapun asas-asas tersebut adalah sebagai berikut:
a. Asas kepastian hukum;
b. Asas keterbukaan;
c. Asas akuntabilitas;
d. Asas perlakuan yang sama dan tidak membedakan asal negara;
e. Asas kebersamaan;
f. Asas efisiensi berkeadilan;
g. Asas berkelanjutan;
h. Asas berwawasan lingkungan;
i. Asas kemandirian; dan

\footnotetext{
${ }^{11}$ Aminuddin Ilmar, Hukum Penanaman Modal, (Jakarta: Prenada Media, 2004), h. 40-43.
} 
j. Asas keseimbangan kemajuan serta kesatuan ekonomi nasional.

Lebih lanjut lagi, tidak dapat dipungkiri, hadirnya investor asing yang berinvestasi diwilayang negara Indonesia menjadi pemotifasi investor-investor dalam negeri untuk lebih meningkatkan kualitas produk atau keahlian dalam hal berinvestasi. Hal tersebut merupakan hal salah satu hal positif asalkan pemerintah tetap memberi batasan-batasan ruang gerak investor asing yang dapat menjadi ancaman bagi home industri kecil. Disamping itu adapun tujuan dari penananman modal asing menurut Undang-undang No.25 tahun 2007 tentang Penanaman Modal pasal 3 adalah sebgai berikut :

a. Meningkatkan pertumbuhan ekonomi nasional;

b. Menciptakan lapangan kerja;

c. Meningkatkan pembangunan ekonomi berkelanjutan;

d. Meningkatkan kemampuan daya saing dunia usaha nasional;

e. Meningkatkan kapasitas dan kemampuan teknologi nasional;

f. Mendorong pengembangan ekonomi kerakyatan;

g. Mengolah ekonomi potensial menjadi kekuatan ekonomi riil dengan menggunakan dana yang berasal, baik dari dalam negeri maupun dari luar negeri; dan

h. Peningkatan kesejahteraan ${ }^{12}$

Berdasarkan realitanya jika dibandingkan antara peminjaman modal (utang) terhadap negara maju yang bersedia meminjamkan modal dengan membuka penanaman modal bag investor asing untuk masuk dan menanamkan modalnya di negara indonesia maka telah jelas yang lebih baik digunakan adalah cara kedua dengan beberapa keuntungan, penjabaran kekurangan dan kelebihannya sebgai berikut:

a. Dengan kita melakukan pinjaman terhadap luar negeri yang biasa disebut dengan hutang luar negeri maka akan semakin mempersulit keadaan negara sendiri dengan sekaligus harus memikir 2 langkah yang harus dilakukan :

1) Membayar hutang dengan cicilan bunganya

\footnotetext{
${ }^{12}$ Undang-undang No.25 tahun 2007 tentang Penanaman Modal, Pasal 3
} 
2) Mengelola modal hasil dari pinjaman hutang luar negeri tersebut

b. Alternatif yang kedua dengan membuka kesempatan terhadap investor asing merupakan langkah yang dengan manfaat dan keuntungan yang cukup besar terhadap perkembangan perekonomian negara :

1) Dengan adanya investor asing maka akan membuka lapangan kerja baru bagi warga negara indonesia untuk dapat bekerja dan secara otomotis akan mengurangi angka pengangguran dinegara.

2) Dengan adanya investor asing maka akan menciptakan para ahli-ahli yang ada didalam negeri dikarenakan telah dilakukannya kesepakatan dan pemberlakuan aturan sesuai Undang-Undang No.25 tahun 2007 pasal 10 berbunyi:

a) Perusahaan penanaman modal dalam memenuhi kebutuhan tenaga kerja harus mengutamakan tenaga kerja warga negara Indonesia.

b) Perusahaan penanaman modal berhak menggunakan tenaga ahli warga negara asing untuk jabatan dan keahlian tertentu sesuai dengan ketentuan peraturan perundang -undangan.

c) Perusahaan penanaman modal wajib meningkatkan kompetensi tenaga kerja warga negara Indonesia melalui pelatihan kerja sesuai dengan ketentuan peraturan perundang-undangan.

d) Perusahaan penanaman modal yang mempekerjakan tenaga kerja asing diwajibkan menyelenggarakan pelatihan dan melakukan alih teknologi kepada tenaga kerja warga negara Indonesia sesuai dengan ketentuan peraturan perundang-undangan.

3) Dengan adanya infestor asing maka akan meningkatkan devisa negara melalui penanaman modal dibidang produksi ekspor, disektor industri penanaman modal asing mengurangi kebutuhan untuk impor, menambah pajak-pajak dan royalti, menambah kempatan kerja, meningkatkan keterampilan kerja serta memberikan pengaruh modernisasi. $^{13}$

\footnotetext{
${ }^{13}$ Aminuddin Ilmar, Hukum Penanaman Modal, (Jakarta: Prenada Media, 2004), h. 72.
} 
4) Dengan adanya investor asing maka, pemerintah membuka jalan bagi pengenalan budaya serta apasaja yang ada didalam negara Indonesia terhadap negara luar.

Dalam hal penanaman modal asing, diatur juga mengenai beberapa bagian usaha yang tidak diberikan adanya kemungkinan penanaman modal asing baik modal penuh maupun kerjasama patungan pada penanaman modal di Indonesia, seperti usaha yang memiliki kedudukan sentral bagi pertahanan suatu negara, antaralain memproduksi bahan peledak, senjataapi, serta perkakas perang terlarang lainnya. Perwujudan aturan tentang bidang usaha penanaman modal asing serta penentuan pengkhususannya bagi pemerintah awal sekali diberlakukan melalui instruksi presidium kabinet No: 06/EK/IN/1969 yang intinya berisikan tentang penetapan bahwa penanaman modal asing diatur pada:

a. Bisnis yang bisa menaikkan penambahan devisa untuk negara, seperti pada kategori bisnis produksi pertanian, pertambangan, Industri ekspor dan lainnya;

b. Bisnis yang dapat meminimalisir impor untuk barang-barang tertentu, antaralain jasa ataupun bahan yang dapat langsung dikonsumsi.

c. Bisnis yang tidak memberikan penambahan devisa namun juga tidak memberikan penurunan impor barang secara berarti, tapi:

1) Sektor usaha yang bisa menghasilkan secara cepat;

2) Sektor usaha yang bisa meningkatkan atau memperluas lapangan pekerjaan;

3) Sektor usaha yang memperkenalkan tekhnologi ataupun metode pembaharuan pekerjaan yang berdampak pada kenaikan produktivitas pada produksi;

4) Sektor usaha yang bisa meningkatkan efektifitas pekerjaan ataupun memperkecil biaya produksi. 


\section{KESIMPULAN}

Bahwa kegiatan menanam modal untuk melakukan usaha di wilayah negara Republik Indonesia yang dilakukan oleh penanam modal asing, baik yang menggunakan modal asing sepenuhnya maupun yang berpatungan dengan penanam modal dalam negeri. Selanjutnya bahwa dari hasil pengamatan dapat disimpulkan bahwa upaya peningkatan perekonomian negara pasca pandemic covid 19 kedepan kaitannya dengan penanaman modal merupakan alternatif yang sangat baik dan telah terbukti dampak positifnya bagi perekonomian negara, dan dengan segala problemnya mengenai ancaman kerusakaan kebudayaan merupaka isu tanpa memikir lebih jauh langkah pengendaliannya. Kiranya dengan adanya PMA maka sebagai motifasi dan pemerintah kiranya lebih meningkatkan pengawasannya terhadap PMA yang telah berinvestasi di Negara Indonesia pasca pandemic covid-19 sehingga perlu penguatan-penguatan melalui kebijakan dari pemerintah untuk mengantisipasi dampak negatif yang disebutkan diatas.

\section{REFERENSI}

Ilmar, Aminuddin. Hukum Penanaman Modal. Jakarta: Prenada media, 2005.

Arsyad. ed.1, Pengantar Perencanaan dan Pembangunan Ekonomi Daerah, Yogyakarta: BPFE, 1999

Jakti, Kuntjoro. Ekonomi Politik di Asia Pasifik. Jakarta: Erlangga,1995.

Lubis, Mulya.T. Hukum Ekonomi, Jakarta: Sinar Harapan, 1992.

Simamora, Henri. Manajemen Pemasaran Internasional. Jakarta: Salemba Empat, 2000.

Undang-undang No.25 Tahun 2007 Tentang Penanaman modal.

Undang-Undang No.1 Tahun 1976 Tentang Penanaman Modal Asing.

Google News, "Virus Corona covid-19" Situs Resmi, https://news.google.com/covid19/map?hl=id\&gl=ID\&ceid=ID\%3Aid November 2020) 
